\title{
Efficacy of Fungicides and Rotational Programs for Management of Powdery Mildew on Cantaloupe
}

\author{
Michael E. Matheron and Martin Porchas, Yuma Agricultural Center, The University of Arizona, Yuma 85364
}

\begin{abstract}
Matheron, M. E., and Porchas, M. 2013. Efficacy of fungicides and rotational programs for management of powdery mildew on cantaloupe. Plant Dis. 97:196-200.

Powdery mildew of cucurbits, caused by Podosphaera xanthii (syn. Sphaerotheca fuliginia auct. p.p. (Schltdl.) Pollacci), is a common and often severe disease in most areas of the world. Field trials were conducted with cantaloupe to compare disease management success provided by conventional fungicides and biofungicides having different inherent efficacies and modes of action, when applied alone throughout the treatment period or as components of fungicide application programs. Additionally, the portion of total disease control provided by each component fungicide within selected rotational programs was determined. When applied alone throughout the treatment period, disease severity in 2008 and 2009 compared with nontreated plants was reduced by values of $100,99.3$, and $98.1 \%$ by wettable sulfur (Microthiol Disperss), triflumizole (Procure), and quinoxyfen (Quintec), respectively; $83.9,76.4$, and $57.4 \%$ by trifloxystrobin (Flint), pyraclostrobin (Cabrio), or azoxystrobin (Quadris), respectively; and 39.8, $31.1,30.0$, and $28.6 \%$ by thiophanate-methyl (Topsin M), potassium bicarbonate (Kaligreen), kresoxim-methyl (Sovran), and Bacillus subtilis (Serenade), respectively. Rotational application programs composed of Microthiol Disperss, Procure, and Quintec reduced powdery mildew severity on cantaloupe by 97.5 to $100 \%$ in both trials. In comparison, disease reduction of 86.0 to $100 \%$ was achieved when the first and third fungicide applications were Quintec or Procure and the second and fourth applications were Cabrio, Flint, Kaligreen, Quadris,

Serenade, Sovran, or Topsin M. In field trials designed to elucidate the portion of total disease control provided by each component fungicide within a rotational program, application sequences of Procure, Streptomyces lydicus (Actinovate), Procure, and Actinovate or Procure, Kaligreen, Procure, and Kaligreen resulted in reductions in powdery mildew severity of 69.1 and $78.7 \%$, respectively. In comparison, inclusion of only the two Procure applications brought about a mean disease reduction of $85 \%$, whereas inclusion of only the two Actinovate or Kaligreen applications reduced the level of powdery mildew control to 17.6 and $12.9 \%$, respectively. The usefulness of fungicides with low inherent efficacy as resistance management partners when applied with highly efficacious at-risk fungicides may be questioned; however, the importance of any fungicide as a resistance management partner should be measured by its ability to dilute the selection pressure of the at-risk fungicide and to inhibit the growth of any resistant biotypes that may arise, factors which may not be reflected by its inherent efficacy in controlling disease. Because less efficacious fungicides did not increase the overall level of disease control, encouraging growers and pest control advisors to incorporate them into powdery mildew treatment programs may be a challenge, because resistance management is not their top priority. An ongoing educational effort emphasizing the benefits of resistance management programs with respect to prolonging the effectiveness of single-site mode of action fungicides is essential.
\end{abstract}

Powdery mildew (PM) of cucurbits, caused by Podosphaera xanthii (syn. Sphaerotheca fuliginia auct. p.p. (Schltdl.) Pollacci), is a severe and common disease in most areas of the world (13). The disease can cause economic losses through reduced yield, decreased fruit quality, and shortened length of time that the crop can be harvested. In Arizona, PM occurs annually in cantaloupe (Cucumis melo L.), watermelon (Citrullus vulgaris Schrad), and mixed melon crops. In maturing desert melon plantings, leaves moderately to heavily infected and damaged by PM rapidly desiccate in the low relative humidity and high-temperature environment present in late spring and early summer, resulting in direct melon loss due to sunscald and decreased quality due to reduced sugar levels in developing fruit.

Fungicides are important PM management tools (13). However, frequent application of fungicide products, especially those containing active ingredients with the same mode of action, can lead to development of resistance to the fungicide within the pathogen population (3). For example, resistance to the fungicides benomyl and triadimefon has been reported in populations of $P$. xanthii throughout the United States (10). This pathogen has demonstrated a high capability for development of resistance in other areas of the world as well $(14,16)$.

Corresponding author: M. E. Matheron, E-mail: matheron@ag.arizona.edu

Accepted for publication 15 August 2012.

http://dx.doi.org/10.1094/PDIS-04-12-0370-RE

(c) 2013 The American Phytopathological Society
The Fungicide Resistance Action Committee (FRAC) has developed strategies to combat the development of fungicide resistance within plant pathogen populations. One of these tactics is to avoid the use of any single product in isolation and, instead, to rely on a mixture or rotation of products containing active ingredients with different modes of action (3). To facilitate the usage of compounds with different modes of action, FRAC assigns a code number to each fungicide based on the product's mode of action. Therefore, even though product trade names and active ingredient names may differ, users can discern that those with the same FRAC code number have a similar mode of action. Updates of lists of fungicides and modes of action are published annually by FRAC (7). However, there may be limitations to the effectiveness of this resistance management strategy. Mathematical models have been published with the goal of predicting the rate of resistance development in relation to different scenarios of fungicide use (4-6). These models suggest that using either mixtures or rotations of fungicides with different modes of action can delay but will not prevent the buildup of resistant variants within populations of plant pathogens exposed to fungicides.

Several different conventional fungicides and biofungicides are registered for use in managing PM on cucurbits in the United States. Some of these materials are also classified as organic disease management products, such as those listed by the Organic Materials Review Institute (OMRI). Individual conventional fungicides as well as biofungicides vary in disease management effectiveness, depending on the inherent activity of the product, sensitivity of the pathogen population to the fungicide, and environmental factors that influence product efficacy, disease development, and intensity $(10,13)$. The efficacy of biofungicides 
for management of PM on cucurbits generally is lower than that provided by registered conventional fungicides $(2,12,19)$. This also was evident in Arizona, where disease pressure in cantaloupe plantings often is severe $(8,9)$. Likewise, combining a biofungicide with a conventional material in a fungicide application program can provide a higher level of disease management over that obtained by use of the biofungicide product alone $(2,8,9,12)$.

To achieve the optimum degree of PM control on melon plantings while, at the same time, employing a rotational application program of two or more chemistries for resistance management, it is imperative to know which combinations of products within treatment programs will be most effective. It is also important to know what portion of the total achieved disease reduction is provided by each component fungicide within a treatment program. Concerning $\mathrm{PM}$ on cantaloupe, the specific objectives of this research were to (i) compare management success provided by conventional fungicides and biofungicides having different inherent efficacies and modes of action, when applied alone throughout the treatment period or when applied as components of fungicide application programs; and (ii) determine the individual contribution to total disease control provided by fungicides of significantly different inherent efficacy.

\section{Materials and Methods}

Disease control with individual fungicides and rotational application programs. Field trials were conducted in 2008 and 2009 at The University of Arizona Yuma Agricultural Center in a silty clay loam soil. Cantaloupe 'Topmark' was seeded 6 March 2008 and 16 March 2009 on beds with $204 \mathrm{~cm}$ between bed centers, then sprinkler irrigated to germinate seed. Subsequent applications of water were made by furrow irrigation. Tested conventional fungicides and biofungicides (Table 1) were each applied alone or within a series of rotational application programs. PM was first observed in late May in previous cantaloupe plantings seeded in early to mid-March; therefore, initial application of fungicides was made in mid-May and continued until crop maturity. Applications were made four times: 14, 22, and 29 May and 6 June 2008 and 18 May and 2, 9, and 16 June 2009. Products were applied with a tractor-mounted boom sprayer, using hollow-cone nozzles spaced $30 \mathrm{~cm}$ apart that delivered 468 liters/ha at $689 \mathrm{kPa}$. Each treatment was replicated five times in a randomized complete block design, with each replicate plot consisting of $7.6 \mathrm{~m}$ of row. Air temperature and relative humidity were recorded hourly at a meteorological station about $500 \mathrm{~m}$ away from the field trials. Disease severity was recorded on 12 June 2008 and 24 June 2009 by collecting 10 leaves from each replicate plot near the base of plants at a distance interval of $0.5 \mathrm{~m}$ and assessing the severity of PM on the upper and the lower leaf surfaces by estimating the proportion of the leaf surface area (0 to $100 \%$ ) covered with the pathogen. Disease ratings were estimated in increments of $5 \%$.

Partitioning of disease control provided by each component within a rotational treatment program. The purpose of this se- ries of trials was to determine the portion of total disease control provided by each component fungicide within selected rotational programs. Fungicides evaluated were Actinovate, Kaligreen, and Procure. Rotational programs included two application sequences: Procure, Actinovate, Procure, and Actinovate or Procure, Kaligreen, Procure, and Kaligreen. Efficacy of these treatment programs was compared with two applications of each product (Procure, Actinovate, or Kaligreen) on the same dates that they were applied within the rotational programs. Also included for evaluation were four consecutive applications of each product. These field trials were conducted in 2008, 2009, and 2010 at The University of Arizona Yuma Agricultural Center. Topmark cantaloupe was seeded 6 March 2008, 16 March 2009, and 22 March 2010 on beds with $204 \mathrm{~cm}$ between bed centers, then sprinkler irrigated to germinate seed. Subsequent applications of water were made by furrow irrigation. Application dates for each trial were 16 and 27 May and 5 and 10 June 2008; 19 May and 1, 8, and 15 June 2009; and 21 May and 2, 11, and 21 June in 2010. Products were applied with a tractor-mounted boom sprayer in the same manner as described earlier, with each treatment replicated five times in a randomized complete block design on replicate plots consisting of $7.6 \mathrm{~m}$ of row. Disease severity was recorded on 17 June 2008, 24 June 2009, and 24 June 2010. Disease severity, air temperature, and relative humidity data were ascertained as described earlier.

Statistical analysis. PM severity data were converted to percent disease control values before statistical analysis by comparing disease severity for each treatment to that in nontreated plots. CoStat statistical software (CoHort Software) was used to perform analysis of variance with the GLM procedure. Means were compared and separated at $P=0.05$ according to Fisher's protected least significant difference.

\section{Results}

Disease development and climactic factors. Small visible PM colonies were initially detected on cantaloupe plant leaves on 27 , 28, and 26 May in 2008, 2009, and 2010, respectively. Disease developed rapidly and was severe by crop maturity in mid- to late June. Mean air temperature during May and June 2008, 2009, and 2010 was 23 to 27 and 28 to $31^{\circ} \mathrm{C}$, respectively, whereas mean relative humidity levels were 35 to $36 \%$ in May and 20 to $33 \%$ in June.

Disease control with individual fungicides and rotational application programs. A high level of disease was present on cantaloupe plant leaves in nontreated plots by crop maturity in both field trials, with mean values of 50 and $60 \%$ of leaf surface area covered with PM in 2008 and 2009, respectively. The level of disease control provided by wettable sulfur (Microthiol Disperss), triflumizole (Procure), and quinoxyfen (Quintec) when applied alone throughout the treatment period was significantly higher than all other products tested in 2008 and 2009 on the upper and lower leaf surfaces (Table 2). Considering both years together, Microthiol Disperss, Procure, and Quintec reduced disease severity, compared

Table 1. Fungicide information

\begin{tabular}{|c|c|c|c|c|}
\hline Product $^{\mathrm{y}}$ & Rate ha ${ }^{-1}$ & Active ingredient & Source & FRAC $\operatorname{code}^{\mathrm{z}}$ \\
\hline Actinovate AG & $425 \mathrm{~g}$ & Streptomyces lydicus & Natural Industries, Inc., Houston, TX & $\mathrm{NC}$ \\
\hline Cabrio 20EG & $1,135 \mathrm{~g}$ & Pyraclostrobin & BASF Ag Products, Research Triangle Park, NC & 11 \\
\hline Flint 50WG & $142 \mathrm{~g}$ & Trifloxystrobin & Bayer CropScience, Research Triangle Park, NC & 11 \\
\hline Kaligreen $82 \mathrm{WP}$ & $5,675 \mathrm{~g}$ & Potassium bicarbonate & Arysta LifeScience North America LLC, Cary, NC & $\mathrm{NC}$ \\
\hline Microthiol Disperss 80WDG & $11,350 \mathrm{~g}$ & Wettable sulfur & United Phosphorus, Inc., King of Prussia, PA & M2 \\
\hline Procure 480SC & $592 \mathrm{ml}$ & Triflumizole & Chemtura Corp., Middlebury, CT & 3 \\
\hline Quadris 25SC & $1,110 \mathrm{ml}$ & Azoxystrobin & Syngenta Crop Protection, Inc., Greensboro, NC & 11 \\
\hline Quintec 250SC & $445 \mathrm{ml}$ & Quinoxyfen & Dow Agrosciences LLC, Indianapolis, IN & 13 \\
\hline Serenade MAX & $2,270 \mathrm{ml}$ & Bacillus subtilis & AgraQuest, Inc., Davis, CA & 44 \\
\hline Sovran 50WG & $344 \mathrm{~g}$ & Kresoxim-methyl & Cheminova, Inc., Research Triangle Park, NC & 11 \\
\hline Topsin M 4.5FL & $740 \mathrm{ml}$ & Thiophanate-methyl & United Phosphorus, Inc., King of Prussia. PA & 1 \\
\hline
\end{tabular}

${ }^{y}$ Adjuvants were applied with the following fungicides and field trials: Silwet L-77, $296 \mathrm{ml} \mathrm{ha}^{-1}$, with Procure and Serenade MAX in 2008 and 2009 and Actinovate AG in 2010 trials; DyneAmic, 1,184 $\mathrm{ml} \mathrm{ha}^{-1}$, with Procure in 2010; and Kinetic, $710 \mathrm{ml} \mathrm{ha}^{-1}$, with Cabrio, Quadris, and Sovran in 2008 and 2009. All tested adjuvants were from Helena Chemical Co., Collier, TN.

${ }^{\mathrm{z}}$ FRAC codes from the Fungicide Resistance Action Committee (http://www.frac.info/frac/publication/anhang/FRAC\%20Code\%20List\%202011-final.pdf) (7). 
with nontreated plants, by mean values of $100,99.3$, and $98.1 \%$, respectively. At the other end of the efficacy spectrum in the same trials, thiophanate-methyl (Topsin M), potassium bicarbonate (Kaligreen), kresoxim-methyl (Sovran), and Bacillus subtilis (Serenade) reduced disease by mean values of 39.8, 31.1, 30.0, and $28.6 \%$, respectively, when applied alone (Table 2). Intermediate levels of mean disease reduction were $83.9,76.4$, and $57.4 \%$ when the fungicides trifloxystrobin (Flint), pyraclostrobin (Cabrio), or azoxystrobin (Quadris), respectively, were applied in the same manner.

Rotational application programs containing the three fungicides Microthiol Disperss, Procure, and Quintec reduced the severity of PM on cantaloupe by mean values of 97.5 to $100 \%$ for both trials (Table 2). In comparison, mean disease reduction values of 86.0 to $100 \%$ were achieved with application sequences starting with Procure; followed by Cabrio, Flint, Kaligreen, Quadris, Serenade, Sovran, or Topsin M; then Quintec; and, finally, another application of Cabrio, Flint, Kaligreen, Quadris, Serenade, Sovran, or Topsin M. For treatment programs as above, except that Quintec and Procure were applied first and third, respectively, in the treatment sequence, reduction of PM was 86.0 to $100 \%$ as well. Finally, if Cabrio, Flint, Kaligreen, Quadris, Serenade, Sovran, or Topsin M was applied initially and at the third application, along with Pro- cure and Quintec at the second and fourth application, respectively, then disease reduction compared with nontreated plants was 71.4 to $100 \%$ (Table 2). All rotational programs that included Cabrio, Flint, Kaligreen, Quadris, Serenade, Sovran, or Topsin M provided statistically better control of PM compared with solitary application of each product for the entire treatment period in 2008 and 2009.

Partitioning of disease control provided by each component within a rotational treatment program. A high level of disease had developed on cantaloupe plants in nontreated plots by crop maturity in all three field trials, with mean values of 55,70 , and $75 \%$ of leaf surface area covered with PM in 2008, 2009, and 2010, respectively. When applied exclusively throughout the four treatment period of each field trial, Procure reduced disease by $90.3 \%$ compared with nontreated plots for the three trials conducted from 2008 to 2010 (Table 3). In comparison, PM reduction provided by Actinovate and Kaligreen for the same time period and treatment number was 26.2 and $28.1 \%$, respectively. The higher efficacy of Procure when compared with Actinovate or Kaligreen was significantly different in each of the three field trials conducted (Table 3).

Product application sequences consisting of Procure, Actinovate, Procure, and Actinovate or Procure, Kaligreen, Procure, and Kali-

Table 2. Effect of fungicides applied alone or in a rotational program on powdery mildew (PM) of cantaloupe in two field trials

\begin{tabular}{|c|c|c|c|c|c|c|c|}
\hline \multirow{2}{*}{\multicolumn{4}{|c|}{ Products and application sequence ${ }^{x}$}} & \multicolumn{4}{|c|}{ Disease control $(\%)^{\mathrm{w}}$} \\
\hline & & & & \multicolumn{2}{|c|}{2008} & \multicolumn{2}{|c|}{2009} \\
\hline First & Second & Third & Fourth & Upper & Lower & Upper & Lower \\
\hline \multicolumn{8}{|l|}{ Single $^{\mathrm{y}}$} \\
\hline Microthiol & Microthiol & Microthiol & Microthiol & $100 \mathrm{a}$ & $100 \mathrm{a}$ & $100 \mathrm{a}$ & $100 \mathrm{a}$ \\
\hline Procure & Procure & Procure & Procure & $100 \mathrm{a}$ & $100 \mathrm{a}$ & $100 \mathrm{a}$ & $97.1 \mathrm{a}-\mathrm{c}$ \\
\hline Quintec & Quintec & Quintec & Quintec & $100 \mathrm{a}$ & $94.2 \mathrm{bc}$ & $100 \mathrm{a}$ & $98.1 \mathrm{ab}$ \\
\hline Flint & Flint & Flint & Flint & $91.5 \mathrm{c}-\mathrm{e}$ & $85.7 \mathrm{gh}$ & $85.0 \mathrm{~h}$ & 73.41 \\
\hline Cabrio & Cabrio & Cabrio & Cabrio & $85.8 \mathrm{f}$ & $73.3 \mathrm{i}$ & $80.0 \mathrm{i}$ & $66.4 \mathrm{~m}$ \\
\hline Quadris & Quadris & Quadris & Quadris & $46.3 \mathrm{~g}$ & $69.5 \mathrm{j}$ & $48.5 \mathrm{j}$ & $65.5 \mathrm{~m}$ \\
\hline Topsin M & Topsin M & Topsin M & Topsin M & $43.7 \mathrm{~g}$ & $44.2 \mathrm{k}$ & $40.5 \mathrm{k}$ & $30.7 \mathrm{n}$ \\
\hline Serenade & Serenade & Serenade & Serenade & $35.8 \mathrm{~h}$ & $29.5 \mathrm{~m}$ & $28.0 \mathrm{~m}$ & 20.9 o \\
\hline Kaligreen & Kaligreen & Kaligreen & Kaligreen & $33.7 \mathrm{~h}$ & $30.9 \mathrm{~m}$ & 32.01 & $27.9 n$ \\
\hline Sovran & Sovran & Sovran & Sovran & $27.3 \mathrm{i}$ & 36.71 & $26.0 \mathrm{~m}$ & $30.2 n$ \\
\hline \multicolumn{8}{|l|}{ Rotational $^{\mathrm{z}}$} \\
\hline Procure & Microthiol & Quintec & Microthiol & $100 \mathrm{a}$ & $100 \mathrm{a}$ & $97.5 \mathrm{a}-\mathrm{c}$ & $100 \mathrm{a}$ \\
\hline Procure & Topsin M & Quintec & Topsin M & $100 \mathrm{a}$ & $97.1 \mathrm{ab}$ & $98.5 \mathrm{a}-\mathrm{c}$ & $90.7 \mathrm{gh}$ \\
\hline Procure & Serenade & Quintec & Serenade & $100 \mathrm{a}$ & $93.3 \mathrm{~cd}$ & $94.0 \mathrm{de}$ & 86.0 aij \\
\hline Procure & Flint & Quintec & Flint & $100 \mathrm{a}$ & $92.8 \mathrm{c}-\mathrm{e}$ & $96.5 \mathrm{de}$ & $94.4 \mathrm{c}-\mathrm{e}$ \\
\hline Procure & Quadris & Quintec & Quadris & $98.9 \mathrm{a}$ & $90.5 \mathrm{~d}-\mathrm{f}$ & $100 \mathrm{a}$ & $96.2 \mathrm{~b}-\mathrm{d}$ \\
\hline Procure & Sovran & Quintec & Sovran & $96.8 \mathrm{ab}$ & $92.3 \mathrm{c}-\mathrm{e}$ & $96.0 \mathrm{~cd}$ & $99.5 \mathrm{a}$ \\
\hline Procure & Cabrio & Quintec & Cabrio & $96.8 \mathrm{ab}$ & $90.0 \mathrm{~d}-\mathrm{f}$ & $97.0 \mathrm{bc}$ & $93.9 \mathrm{~d}-\mathrm{f}$ \\
\hline Procure & Kaligreen & Quintec & Kaligreen & $90.5 \mathrm{de}$ & $94.3 \mathrm{gh}$ & $100 \mathrm{a}$ & $91.2 \mathrm{f}-\mathrm{h}$ \\
\hline Quintec & Microthiol & Procure & Microthiol & $100 \mathrm{a}$ & $100 \mathrm{a}^{\circ}$ & $100 \mathrm{a}$ & $100 \mathrm{a}$ \\
\hline Quintec & Kaligreen & Procure & Kaligreen & $100 \mathrm{a}$ & $100 \mathrm{a}$ & $99.5 \mathrm{ab}$ & 88.4 hi \\
\hline Quintec & Flint & Procure & Flint & $98.4 \mathrm{a}$ & $92.4 \mathrm{c}-\mathrm{e}$ & $98.5 \mathrm{a}-\mathrm{c}$ & $88.4 \mathrm{hi}$ \\
\hline Quintec & Serenade & Procure & Serenade & $98.4 \mathrm{a}$ & 89.5 ef & $97.0 \mathrm{bc}$ & $86.0 \mathrm{ij}$ \\
\hline Quintec & Quadris & Procure & Quadris & $97.3 \mathrm{ab}$ & $99.0 \mathrm{a}$ & $100 \mathrm{a}$ & $100 \mathrm{a}$ \\
\hline Quintec & Topsin M & Procure & Topsin M & $94.2 \mathrm{bc}$ & $90.4 \mathrm{~d}-\mathrm{f}$ & 94.0 de & $98.0 \mathrm{ab}$ \\
\hline Quintec & Cabrio & Procure & Cabrio & $93.1 \mathrm{~cd}$ & $90.0 \mathrm{~d}-\mathrm{f}$ & $100 \mathrm{a}$ & 88.9 hi \\
\hline Quintec & Sovran & Procure & Sovran & $93.1 \mathrm{~cd}$ & $87.6 \mathrm{fg}$ & $96.5 \mathrm{~cd}$ & $93.0 \mathrm{e}-\mathrm{g}$ \\
\hline \multicolumn{8}{|l|}{ Other } \\
\hline Microthiol & Procure & Microthiol & Quintec & $100 \mathrm{a}$ & $100 \mathrm{a}$ & $100 \mathrm{a}$ & $100 \mathrm{a}$ \\
\hline Flint & Procure & Flint & Quintec & $100 \mathrm{a}$ & $99.0 \mathrm{a}$ & $100 \mathrm{a}$ & $100 \mathrm{a}$ \\
\hline Topsin M & Procure & Topsin $\mathrm{M}$ & Quintec & $100 \mathrm{a}$ & $100 \mathrm{a}$ & $97.5 \mathrm{a}-\mathrm{c}$ & 88.9 hi \\
\hline Cabrio & Procure & Cabrio & Quintec & $99.5 \mathrm{a}$ & $98.1 \mathrm{a}$ & $100 \mathrm{a}$ & $93.0 \mathrm{e}-\mathrm{g}$ \\
\hline Serenade & Procure & Serenade & Quintec & $97.9 \mathrm{a}$ & $84.7 \mathrm{gh}$ & 92.0 ef & $86.0 \mathrm{ij}^{\circ}$ \\
\hline Quadris & Procure & Quadris & Quintec & $92.6 \mathrm{~cd}$ & $85.2 \mathrm{gh}$ & $89.5 \mathrm{fg}$ & $84.6 \mathrm{j}$ \\
\hline Kaligreen & Procure & Kaligreen & Quintec & $91.5 \mathrm{c}-\mathrm{e}$ & $71.4 \mathrm{ij}$ & $90.0 \mathrm{fg}$ & $79.1 \mathrm{k}$ \\
\hline Sovran & Procure & Sovran & Quintec & 88.4 ef & $83.3 \mathrm{~h}$ & $88.5 \mathrm{~g}$ & $80.5 \mathrm{k}$ \\
\hline
\end{tabular}

${ }^{\mathrm{w}}$ Mean disease severity values of 50 and $60 \%$ of leaf surface area covered with PM in nontreated plots were recorded in 2008 and 2009 , respectively. Percent disease control values were derived by comparing disease severity of each treatment to that in nontreated plots. Values in each column followed by a different letter are significantly different $(P=0.05)$ according to Fisher's protected least significant difference.

x Treatment dates were 14, 22, and 29 May and 6 June 2008; and 18 May and 2, 9, and 16 June 2009. Small PM colonies were first observed on some plants on 27 May 2008 and 28 May 2009.

y Application of single product for duration of trial.

${ }^{\text {z }}$ Rotational programs starting with Procure, Quintec, or other fungicides (Other). 
green led to reductions in PM of 69.1 and $78.7 \%$, respectively, for the three trials (Table 3 ). Within the treatment programs for the same trials, inclusion of only the two Procure applications resulted in a mean disease reduction of $85 \%$ for the three trials, whereas inclusion of only the two Actinovate or Kaligreen treatments reduced the level of PM control to 17.6 and $12.9 \%$, respectively, compared with nontreated plants. The difference in disease reduction between two applications of Procure compared with the same number of applications of Actinovate or Kaligreen was significant in each of the three trials. In two of three trials, reduction of PM recorded for the treatment program containing only two applications of Procure (with alternating applications of Actinovate or Kaligreen deleted) was significantly higher than that for treatment programs containing Procure and Actinovate or Kaligreen (Table 3). Finally, four applications of Procure provided a significantly higher level of PM control than two applications of this fungicide in two of three trials, whereas four applications of Actinovate or Kaligreen were significantly superior to two applications of each product in all three field trials.

\section{Discussion}

The cucurbit PM pathogen P. xanthii has a high potential for development of resistance to fungicides (10). The first case of fungicide resistance in the United States reported with this cucurbit pathogen was with benomyl (Benlate), a FRAC code 1 chemistry (17). Subsequent resistance of $P$. xanthii to thiophanate-methyl (Topsin M, FRAC code 1), triadimefon (Bayleton, FRAC code 3), trifloxystrobin (Flint, FRAC code 11), and myclobutanil (Nova, Rally, FRAC code 3) has been noted in the United States as well $(10,11)$. All of these conventional fungicides as well as those most recently registered for PM on cucurbits are single-site mode of action chemistries which have a tendency toward resistance development. It is extremely important to use these compounds in a manner that will minimize development of resistance within the pathogen population. FRAC has developed a series of fungicide resistance management guidelines, including (i) not using a single chemistry exclusively, (ii) restricting the number of applications per season, (iii) using the manufacturer's application rate, (iv) applying fungicides as preventative protectants rather than as eradicants, and (v) encouraging use of products with different modes of action during the season. Brent and Hollomon (3) concluded that combining the use of these different strategies is feasible, beneficial, and often implemented. However, mathematical models suggest that using mixtures or rotations of fungicides with different modes of action can delay but will not prevent fungicide resistance (4-6). An additional FRAC fungicide resistance management strategy is the use of integrated disease management. This concept, incorporating the use of resistant varieties, biological control agents, and crop rotation, could be a robust integrated strategy for further delaying the onset of fungicide resistance when used in conjunction with the other FRAC guidelines (3).
Several conventional fungicides and biofungicides are currently registered in the United States for managing PM on melons. However, data presented in this article demonstrated that tested products applied season long were not equally effective at managing the disease on cantaloupe plants. The efficacy of individual products tested in 2008 and 2009 on upper and lower leaf surfaces ranged from a high of 94.2 to $100 \%$ reduction of PM, as compared with nontreated plants, on cantaloupe plants treated with Microthiol Disperss, Procure, or Quintec, to a low of 20.9 to $35.8 \%$ reduction in disease on plants treated solely with Kaligreen, Serenade, or Sovran. However, in rotational application programs where highly effective fungicides were alternated with products of low to moderate innate efficacy, the resulting reduction in disease severity ranged from 71.4 to $100 \%$. This level of reduction in disease at crop maturity would be acceptable to most Arizona growers, given that this represents an average of 10 or fewer PM colonies per cantaloupe leaf at crop maturity, which is not sufficient disease severity to cause leaf desiccation and destruction before the crop is harvested. Data from these trials suggest that effective levels of disease control can be achieved in desert melon production conditions with any rotational fungicide application program alternating between a highly efficacious product, such as Microthiol Disperss, Procure, or Quintec, and a product of moderate to low efficacy, such as Flint, Cabrio, Quadris, Topsin M, Serenade, Kaligreen, or Sovran. Because several modes of action are represented in this list of materials, there would be ample opportunity to deploy fungicide application programs that would concurrently provide acceptable levels of disease control as well as resistance management within the PM pathogen population.

Wettable sulfur provided excellent control of PM in these trials when applied to cantaloupe plantings alone or in a rotational program with other fungicides. Sulfur has long been an excellent product for managing PM and is listed by OMRI for use in organic production systems. As a multi-site fungicide with low resistance development potential, sulfur is an excellent partner in rotational programs along with an at-risk fungicide. However, one disadvantage to sulfur is the potential for burning of leaves on some cantaloupe cultivars during hot (temperatures above $30^{\circ} \mathrm{C}$ ) and dry weather (1), which is a common occurrence in desert melon production fields.

The efficacy of individual fungicides applied season long compared with the effectiveness of rotational application programs including the same products suggests that the highly effective fungicides are providing the greater share of the total amount of disease control delivered. Further evidence on this point is shown by the fungicide deletion trials within treatment programs containing the highly effective fungicide Procure alternated with Actinovate or Kaligreen, products with low fundamental efficacy. When either Actinovate or Kaligreen was deleted from the treatment program sequence in three field trials, the mean disease reduction provided by the two remaining Procure applications was $85.0 \%$.

Table 3. Individual contribution provided by each fungicide within rotational application programs to the total level of powdery mildew (PM) control on cantaloupe

\begin{tabular}{|c|c|c|c|c|c|c|}
\hline \multicolumn{4}{|c|}{ Products and application sequence $^{y}$} & \multicolumn{3}{|c|}{ Disease control $(\%)^{\mathrm{z}}$} \\
\hline First & Second & Third & Fourth & 2008 & 2009 & 2010 \\
\hline Procure & Actinovate & Procure & Actinovate & $78.5 \mathrm{~b}$ & $53.4 \mathrm{~d}$ & $75.3 \mathrm{~b}$ \\
\hline Procure & Kaligreen & Procure & Kaligreen & $80.5 \mathrm{~b}$ & $82.0 \mathrm{c}$ & $73.6 \mathrm{~b}$ \\
\hline Procure & $\ldots$ & Procure & $\ldots$ & $91.3 \mathrm{a}$ & $88.4 \mathrm{~b}$ & $75.3 \mathrm{~b}$ \\
\hline$\ldots$ & Actinovate & $\ldots$ & Actinovate & $25.7 \mathrm{e}$ & $14.1 \mathrm{f}$ & $12.9 \mathrm{~d}$ \\
\hline 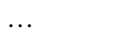 & Kaligreen & $\ldots$ & Kaligreen & $12.3 \mathrm{f}$ & $15.0 \mathrm{f}$ & $11.3 \mathrm{~d}$ \\
\hline Procure & Procure & Procure & Procure & $93.8 \mathrm{a}$ & $97.7 \mathrm{a}$ & $79.3 \mathrm{a}$ \\
\hline Actinovate & Actinovate & Actinovate & Actinovate & $29.2 \mathrm{~d}$ & $29.1 \mathrm{e}$ & $20.4 \mathrm{c}$ \\
\hline Kaligreen & Kaligreen & Kaligreen & Kaligreen & $36.7 \mathrm{c}$ & $29.1 \mathrm{e}$ & $18.4 \mathrm{c}$ \\
\hline
\end{tabular}

y Treatment dates were 16 and 27 May and 5 and 10 June 2008; 19 May and 1, 8, and 15 June 2009; and 21 May and 2, 11, and 21 June 2010. Small PM colonies were first observed on some plants on 27 May 2008, 28 May 2009, and 26 May 2010.

${ }^{\mathrm{z}}$ Mean disease severity values of 55, 70, and 75\% of leaf surface area covered with PM in nontreated plots were recorded in 2008, 2009, and 2010, respectively. Percent disease control values were derived by comparing disease severity of each treatment to that in nontreated plots. Values in each column followed by a different letter are significantly different $(P=0.05)$ according to Fisher's protected least significant difference. 
However, if Procure was deleted from the treatment sequence, the reduction of PM in the same trials provided by the remaining two applications of Actinovate or Kaligreen was only 17.6 and $12.9 \%$, respectively. When viewed in this manner, we get a more accurate measure of the role of each component fungicide within a particular rotational application program. Valuable information on individual fungicide performance within fungicide application programs could be gathered by examining more fungicides within rotational programs in this manner.

Products such as Actinovate and Kaligreen are often recommended as alternation partners with other fungicides for resistance management. However, at least in these field trials conducted in the arid desert environmental conditions of Arizona, where disease severity is usually high, the reduction of PM provided by these materials in treatment programs was minimal compared with that provided by the fungicide Procure. The large disparity in the efficacy of Actinovate and Kaligreen compared with Procure may bring into question the usefulness of these materials, as well as other products with low to moderate efficacy, as effective resistance management partners in controlling PM. The importance of any product with respect to its role as a resistance management partner within a treatment program is its ability to dilute the selection pressure of the at-risk fungicide and to inhibit the growth of any resistant biotypes that may arise (3). The companion compound can be a multi-site product known to possess a low risk for bringing about resistance or a single-site fungicide not related to its partner by mode of action or known cross-resistance (3). Because Kaligreen and the biofungicide Actinovate have either multi-site activity on the PM pathogen or a low potential for resistance development, their usefulness as a resistance management partner may not be dependent on their absolute direct effect on disease reduction in the field. The value of single-site conventional chemistries with low to moderate efficacy as resistance management partners would be dictated by the factors noted above as well. Perhaps achieving the dilution of selection pressure and inhibition of growth of resistant biotypes may not demand efficacy equivalence of the resistance management partner and the at-risk fungicide. Several agrochemical companies currently sell many fungicide products containing two active ingredients, each possessing a different mode of action. It is unlikely that each active ingredient would have equivalent efficacy with respect to each of the pathogens and respective diseases found on the labels of these products, even though these prepackaged mixtures usually are sold with the purpose of facilitating resistance management.

Evaluation of the long-term effects of partner fungicides on the development of resistance to at-risk chemistries is difficult to achieve in field studies, due to complications such as movement of inoculum between plots, interchange of inoculum from sources outside the experimental area, and year-to-year variation in disease pressure. In spite of these constraints, some field trials have demonstrated a positive effect of a partner fungicide on reducing resistance development to an at-risk fungicide. O'Brien et al. (15) reported that $P$. xanthii (syn. $S$. fuliginea) populations on cantaloupe subjected to a spray program that included the protectant fungicide oxythioquinox alone or in alternation with the systemic product triadimefon developed a lower proportion (66 to 73\%) of resistant strains compared with those treated with triadimefon alone (89\%). In another study involving PM on grape caused by Erysiphe necator (syn. Uncinula necator), resistance development to triadimenol by the pathogen was reduced when application of this chemistry was alternated with sulfur (18). Also, in the black sigatoka pathosystem, resistance to triazoles within the population of Mycosphaerella fijiensis was lower following treatments including a tank mix of Serenade and a systemic fungicide alternated with a Serenade application compared with treatment programs without Serenade (D. Manker, personal communication).
Because less efficacious fungicides did not increase the overall level of disease control in these trials, encouraging growers and pest control advisors to incorporate them into PM treatment programs may be a challenge, because resistance management is not their top priority. Product manufacturers can control the exposure of an at-risk fungicide to the threat of resistance development within a pathogen population by language on the product label, which can dictate the rate and number of applications permissible as well as when and how to mix or alternate the at-risk fungicide with products of differing modes of action. Manufacturers also can sell the at-risk fungicide prepackaged with another fungicide to facilitate resistance management. Several pre-packs are available in the United States for managing PM on cucurbits, such as azoxystrobin + chlorothalonil (Quadris Opti), azoxystrobin + difenoconazole (Quadris Top), difenoconazole + cyprodinil (Inspire Super), and pyraclostrobin + boscalid (Pristine). Finally, an ongoing educational effort focusing on the benefits of resistance management programs with respect to prolonging the effectiveness of single-site mode of action fungicides is essential.

\section{Literature Cited}

1. Agrios, G. N. 2005. Plant Pathology, 5th ed. Elsevier Academic Press, San Diego, CA

2. Bay, I. S., Janousek, C. N., Herche, R. W., and Gubler, W. D. 2010. Management of cucurbit powdery mildew with organic and synthetic fungicides, 2009. Plant Dis. Manage. Rep. 4:V085. Online publication. doi:10.1094/ PDMR04

3. Brent, K. J., and Hollomon, D. W. 2007. Fungicide resistance in crop pathogens. How can it be managed. FRAC Monogr. No. 1 (second, revised edition). CropLife International, Brussels.

4. Brent, K. J., and Hollomon, D. W. 2007. Fungicide resistance: the assessment of risk. FRAC Monogr. No. 2 (second, revised edition). Croplife International, Brussels.

5. Brent, K. J., Holloman, D. W., and Shaw, M. W. 1990. Predicting the evolution of fungicide resistance. Pages 303-319 in: Managing Resistance to Agrochemicals. M. B. Green, H. M. LeBaron, and W. K. Moberg, eds. American Chemical Society, Washington, DC.

6. Fry, W. E., and Milgroom, M. G. 1990. Population biology and management of fungicide resistance. Pages 275-285 in: Managing Resistance to Agrochemicals. M. B. Green, H. M. LeBaron, and W. K. Moberg, eds. American Chemical Society, Washington, DC.

7. Fungicide Resistance Action Committee. 2011. Feb. 2011. http://www.frac. info/frac/publication/anhang/FRAC\%20Code\%20List\%202011-final.pdf

8. Matheron, M. E., and Porchas, M. 2007. Efficacy of fungicides for management of powdery mildew on muskmelon, 2006. Plant Dis. Manage. Rep. 1:V073. Online publication. doi:10.1094/PDMR01

9. Matheron, M. E., and Porchas, M. 2008. Comparison of fungicides for management of powdery mildew on muskmelon, 2007. Plant Dis. Manage. Rep. 2:V085. Online publication. doi:10.1094/PDMR02

10. McGrath, M. T. 2001. Fungicide resistance in cucurbit powdery mildew: experiences and challenges. Plant Dis. 85:236-245.

11. McGrath, M. T. 2005. Occurrence of resistance to QoI, DMI, and MBC fungicides in Podosphaera xanthii in 2004 and implication for controlling cucurbit powdery mildew. Resist. Pest Manage. Newsl. 14:36-40.

12. McGrath, M. T., and Shishkoff, N. 1999. Evaluation of biocompatible products for managing cucurbit powdery mildew. Crop Prot. 18:471-478.

13. McGrath, M. T., and Thomas, C. E. 1996. Powdery mildew. Pages $28-30$ in: Compendium of Cucurbit Diseases. T. A. Zitter, D. L. Hopkins, and C. E. Thomas, eds. American Phytopathological Society, St. Paul, MN.

14. O'Brien, R. G. 1994. Fungicide resistance in populations of cucurbit powdery mildew (Sphaerotheca fuliginea). N. Z. J. Crop Hortic. Sci. 22:145-149.

15. O'Brien, R. G., Vawdrey, L. L., and Glass, R. J. 1988. Fungicide resistance in cucurbit powdery mildew (Sphaerotheca fuliginea) and its effect on disease control. Aust. J. Exp. Agric. 28:417-423.

16. Schepers, H. T. A. M. 1984. Persistence of resistance to fungicides in Sphaerotheca fuliginea. Neth. J. Plant Pathol. 90:165-171.

17. Schroeder, W. T., and Provvidenti. 1969. Resistance to benomyl in powdery mildew of cucurbits. Plant Dis. Rep. 53:271-275.

18. Steva, H. 1994. Evaluating anti-resistance strategies for control on Uncinula necator. Pages 59-66 in: Fungicide Resistance. S. Heaney, D. Slawson, D. W. Hollomon, M. Smith, P. E. Russell, and D. W. Parry, eds. British Crop Protection Council, Farnham, Surry, UK.

19. Zhang, S., Vallad, G. E., White, T. L., and Huang, C.-H. 2011. Evaluation of microbial products for management of powdery mildew on summer squash and cantaloupe in Florida, Plant Dis. 95:461-468. 